\title{
Complete response of severe, refractory, gastric, stomal and sclerotherapy-induced esophageal ulcer disease to omeprazole therapy
}

\author{
EARL P. MORGAN, MD, C.N. Williams, MD, FRCPC, FACP
}

\begin{abstract}
This report presents three unusual forms of resistant peptic ulcer disease, all healed completely with the use of a new class of anti-ulcer drug, a proton pump blocker, omeprazole. Each of these patients represents an unusual facet of acid-pepsin disease, namely, resistance to healing with current standard therapy, recurrence and rehealing with a second course of omeprazole, and a subsequent need for maintenance omeprazole to remain ulcer-free. The first patient had an unusual complication of a stomal ulcer after gastric bypass surgery for morbid obesity. This ulcer proved to be intractable, not healing with standard therapy, but healing with omeprazole, and subsequently recurring. A second course of therapy resulted in complete rehealing, but maintenance therapy with omeprazole was necessary to prevent ulcer recurrence. The second patient had rheumatoid arthritis and an NSAID associated chronic gastric ulcer which did not heal with standard therapy. A course of omeprazole resulted in complete healing; however, the ulcer recurred. A second course of omeprazole was necessary which led to complete healing, and subsequent maintenance therapy has kept this patient ulcer-free for the past 18 months. The third patient had recurrent circumferential esophageal ulcers following esophageal variceal sclerotherapy along with primary biliary cirrhosis. These ulcers took five months to heal on conventional therapy, but treatment with omeprazole resulted in healing within a three month time frame, and maintenance omeprazole has since kept this patient free from esophageal ulcers. Can J Gastroenterol 1989;3(5):179-181
\end{abstract}

Key Words: Omeprazole, Refractory ulcer disease

Division of Gastroenterology, Department of Medicine, Dalhousie University, Halifax, Nova Scotia Correspondence and reprints: Dr C.N. Williams, Room CD-1, Clinical Research Centre, 5849 University Avenue, Halifax, Nova Scotia B3H 4H7. Telephone (902) 424-2333

Presented at the symposium 'Focus on gastric proton pump inhibitors: An update on the treatment decisions in peptic ulcer disease'. May 1989, Toronto, Ontario

Received for publication June 29, 1989. Accepted October 3, 1989
$\mathrm{R}$ EFRACTORY ULCER DISEASE, BY DEFINition, implies the continuance of significant morbidity and the risk of significant complications despite aggressive medical management. The medical armamentarium continues to expand; different classes of drugs are being introduced at regular intervals, while a small proportion of patients with refractory disease continue to experience symptoms and have endoscopically demonstrable ulcers.

Omeprazole, a substituted benzimidazole, specifically inhibits the $\mathrm{H}^{+}, \mathrm{K}^{+}$ATPase enzyme in the parietal cell, effectively blocking the final step in the production of gastric acid (1). This decrease in gastric acid occurs in both the fed and fasting states (2-4). The rationale for the use of this class of drugs in the treatment of ulcer disease has thus been established (5). Omeprazole is much more potent than the $\mathrm{H}_{2}$ blockers in suppressing acid secretion, and should be of major benefit to patients with refractory ulcers. Herein are presented three unusual patients, each with symptoms over at least two years, who, after 


\section{La réponse complète d'ulcères sévères, réfractaires, gastriques et esophagiennes après de la sclérothérapie, à la thérapie avec oméprazole}

RESUME: Ce rapport présente trois formes inhabituelles d'ulcère gastro-duodénal rebelle, dont la guérison complète a été obtenue grâce à l'usage d'une nouvelle catégorie de médicaments anti-ulcéreux: l'oméprazole, agent bloquant de la pompe protonique. Chacun des patients représente une facette rare des troubles liés à l'acidité gastrique et à la pepsine-résistance à la thérapie conventional, récidive, deuxième guérison obtenue par un second traitement par l'oméprazole; une thérapie d'entretien à l'oméprazole a été nécessaire à la prévention définitive de toute récurrence. Le premier patient présentait une complication rare d'ulcère peptique consécutif à une dérivation gastrique exécutée pour traiter une obésité grave. Cet ulcère, qui s'était avéré rebelle au traitement conventional, a été guéri par l'oméprazole mais a récidivé. Une seconde cure a abouti à une guérison complète mais un traitement d'entretien par oméprazole a été nécessaire à la prévention d'une récurrence ulcéreuse. Atteint de polyarthrite rhumatoïde, le second patient souffrait d'un ulcère gastrique chronique associé aux anti-inflammatoires non-stéroïdiens et réfractaire au traitement conventional. Un premier traitement par l'oméprazole a abouti à la guérison complète, mais l'ulcère a récidivé. Il a fallu recourir à une seconde cure d'oméprazole pour obtenir une guérison totale, et un traitement d'entretien subséquent pour empêcher la récidive ulcéreuse au cours des 18 derniers mois. Le troisième patient, en plus d'une cirrhose biliaire primitive, était atteint d'ulcères esophagiens circonférentieis récidivants, consécutifs à une sclérothérapie pratiquée pour traiter des varices esophagiennes. La guérison de ces ulcères avait pris cinq mois avec un traitement conventional, mais l'oméprazole a provoqué la guérison en trois mois et le traitement d'entretien par l'oméprazole a depuis empêché toute récidive d'ulcères esophagiens chez ce patient.

aggressive medical management, demonstrated early recurrence or refractoriness of their ulcer disease such that they required treatment with omeprazole to heal their ulcers completely as well as omeprazole maintenance therapy to remain ulcer-free. Gastric mucosal biopsies on gastroscopy every three months have shown no enterochromaffin-like cell proliferation.

\section{CASE STUDIES}

Case A: Patient A is a 27-year-old female who underwent gastric bypass surgery for morbid obesity. She subsequently developed symptoms suggestive of peptic ulcer disease and had an endoscopically proven $(1 \mathrm{~cm})$ stomal ulcer in December 1986. The patient was treated with sucralfate $1 \mathrm{~g}$ qid and ranitidine $150 \mathrm{mg}$ bid with no improvement of symptoms. Indeed, a repeat gastroscopy after eight weeks of treatment revealed that the initial ulcer was partially healed, but that three new superficial ulcers were present. Serum gastrin was normal at $40 \mathrm{ng} / \mathrm{mL}$. Misoprostol $200 \mu \mathrm{g}$ qid was added; however, two months later a re- peat gastroscopy revealed active ulceration, corresponding to a worsening of the patient's symptoms.

Treatment of this patient's chronic, resistant ulcer in May 1987 with omeprazole $20 \mathrm{mg}$ daily for four weeks resulted in ulcer healing and the complete loss of symptoms; treatment was then stopped. In January 1988 the ulcer symptoms recurred, and a large $3 \mathrm{~cm}$ anastomotic ulcer was seen on endoscopy. Omeprazole therapy was restarted and 12 weeks later the ulcer was $99 \%$ healed. The patient was then maintained on omeprazole $20 \mathrm{mg}$ every second day and remained asymptomatic. In July 1988, a gastroscopy revealed no evidence of stomal ulceration. In January 1989, a small stomal ulcer had recurred. The omeprazole dose was increased to $20 \mathrm{mg}$ daily, leading to complete healing. Continued therapy at this dose has resulted in no endoscopically demonstrable ulcer recurrence.

Case B: A 50-year-old female presented with a histologically proven, benign, chronic $(2 \mathrm{~cm})$, gastric ulcer in May 1986. This patient was anemic with active rheumatoid arthritis requiring continued
NSAID therapy (piroxicam); she also had active extensive psoriasis, which required continuous weekly methotrexate therapy. She had had abdominal symptoms of ulcer disease for more than two years and required antacids, sucralfate $1 \mathrm{~g}$ qid and ranitidine $150 \mathrm{mg}$ bid, all without sustained benefit. Omeprazole $20 \mathrm{mg}$ daily was then given, resulting in shrinkage of the ulcer to $4 \mathrm{~mm}$ after four weeks and total healing at eight weeks. Ulcer symptoms disappeared after eight days. Omeprazole was then discontinued and ranitidine $150 \mathrm{mg}$ bid was restarted. Endoscopy in October 1986 showed a few scattered erosions, and in January 1987 two gastric ulcers were seen. Sucralfate $1 \mathrm{~g}$ qid was started and ranitidine discontinued. In March 1987, no change in ulcer healing had occurred and misoprostol $200 \mu \mathrm{g}$ qid was added. In late April, repeat endoscopy confirmed a chronic deep gastric ulcer with multiple erosions. Ranitidine had been restarted as the only medication, as misoprostol had provoked intolerable diarrhea. A second course of omeprazole $40 \mathrm{mg}$ daily was started and at eight weeks gastroscopy revealed complete healing. In March 1988, the omeprazole dose was reduced to $20 \mathrm{mg}$ daily, and the patient has remained symptom-free with maintained healing to this day.

Case C: A 65-year-old female patient with primary biliary cirrhosis and esophageal and fundal varices developed recurrent circumferential esophageal ulcers after successful sclerotherapy for life threatening bleeding (six injections of $5 \%$ ethanolamine given over three months). Sequential treatment with ranitidine $150 \mathrm{mg}$ bid, famotidine $40 \mathrm{mg}$ daily and sucralfate $1 \mathrm{~g}$ qid, prescribed by different physicians, failed to heal these ulcers. A combination of famotidine and sucralfate eventually healed the ulcers after five months; however, they recurred with severe heartburn and dysphagia in October 1988. Endoscopy showed circumferential esophageal ulcers with gastric erosions. Omeprazole $20 \mathrm{mg}$ daily was started, and within three months all ulceration was healed with a complete loss of symptoms. Omeprazole was continued at the same dose and has kept the patient free from esophageal ulcers to date. 


\section{DISCUSSION}

These cases represent three scenarios in which standard medical treatment failed to alleviate symptoms, and ulcers did not heal or recurred while on treatment. Patient $A$ had a deep, anastomotic ulcer occurring after bariatric surgery for morbid obesity. Stomal ulcers following this operation are rare. In a review of the authors' first 100 patients undergoing this procedure, this complication did not occur (6). When the ulcer did not heal with appropriate ranitidine therapy, consideration was given for surgical therapy. However, technical considerations and increased operative risk swayed the judgement in favour of omeprazole therapy. When the ulcer recurred, hyperacidic conditions were considerations; however, serum gastrin was within normal limits.

Patient $B$ had recurrent gastric ulcers complicated by recurrent bleeding, compromising a poor general medical condition from progressive rheumatoid arthritis requiring continuous NSAID use, and severe widespread psoriasis requiring methotrexate therapy. The ulcers

\section{REFERENCES}

1. Wallmark B. Mechanisms of action of omeprazole. Scand J Gastroenterol 1986;118:11-7.

2. Londong W, Londong V, Cederberg C, Steffan H. Dose-response study of omeprazole on meal-stimulated gastric acid secretion and gastrin release. Gastroenterology 1983;85:1373-6.

3. Howden CW, Reid JL, Forrest JAH. Effect of omeprazole on gastric acid secretion in human volunteers. Gut 1983;24:4974.

4. Sharma BK, Watt RP. Pounder RE, Gomez M de Fe, Wood EC, Logan LH. Optimal dose of oral omeprazole for maximal 24 hour decrease of intragastric acidity. Gut 1984;25:957-64. were intractable to conventional $\mathrm{H}_{2}$ blocker therapy and recurred after omeprazole was discontinued and on low dose omeprazole therapy ( $20 \mathrm{mg}$ daily). Complete healing and no recurrences have been achieved with omeprazole $40 \mathrm{mg}$ daily.

Severe ulcerated esophagitis is difficult to heal with conventional or high dose $\mathrm{H}_{2}$ blocker therapy (7). Consequently, when patient $\mathrm{C}$ did not improve, there were few alternatives. Fortunately, omeprazole therapy, found to be successful in other patients with resistant peptic ulcer problems, also proved successful here in completely eradicating the sclerotherapy induced, intractable, circumferential ulcers. In nonsclerotherapy-induced, resistant esophageal ulceration, omeprazole therapy is also reported to be effective $(8,9)$ and has been reviewed (10).

The long term use of omeprazole in all three patients has resulted in no apparent clinical, hematologic, biochemical or histological abnormalities attributable to omeprazole. Patients with duodenal ulcers treated with omeprazole ini-

5. Gustavsson S, Adami HO, Lööf L, et al. Rapid healing of duodenal ulcers with omeprazole: Double-blind, dosecomparative trial. Lancet 1983;ii: 124-5.

6. Anand SV, Williams CN. Gastric bypass in Nova Scotia: An analysis of 100 patients. Can J Surg 1984;27:228-9.

7. Stalnikowicz-Darvasi $\mathrm{R}$. $\mathrm{H}_{2}$ antagonists in the treatment of reflux esophagitis: $\mathrm{A}$ critical analysis. Am J Gastroenterol 1989;84:245-8.

8. Hetzel DJ, Dent J, Reed WD, et al. Healing and relapse of severe peptic esophagitis after treatment with omeprazole. Gastroenterology 1988:95:903-12.

9. Brunner G, Creutzfeldt W, Havke U, Lamberts R. Therapy with omeprazole tially had a mild unexplained rise in serum transaminases (5). Subsequent studies have not confirmed hepatotoxicity $(11,12)$. Repeat protocol biopsies and repeat gastroscopies in the authors' patients over three years have not revealed any histologic abnormalities such as enterochromaffin-like (ECL) cell hyperplasia or proliferation, a particular worry with long term omeprazole treatment in humans; the toxicity data may be species specific (13). The need for continued long term studies is obvious, including the effect of a sustained elevation of serum gastrin levels.

This study of omeprazole therapy in refractory gastric, esophageal and stomal ulcers has demonstrated its effectiveness with regard to the amelioration of symptoms and healing. Each patient requires dose monitoring for recurrence, and individual doses for an ulcer-free life. The number of patients in this study is admittedly small, but in view of the response to omeprazole, it is suggested that this drug be considered for the treatment and prophylaxis of unusual variants of refractory ulcer disease.

in patients with peptic ulcerations resistant to extended high dose ranitidine treatment. Digestion 1988;39:80-90.

10. Howard JM. Omeprazole in the treatment of reflux disease. Can J Gastroenterol 1989;3(Suppl A):62A-6A.

11. Sölvell L. Clinical safety of omeprazole. Can J Gastoenterol 1989;3(Suppl A): $91 \mathrm{~A}-7 \mathrm{~A}$.

12. Sharma BK, Santana IA, Watt RP, et al. Omeprazole and liver function tests. Lancet $1983 ; \mathrm{ii}: 346$.

13. Hakanson R, Sandler F, Carlsson E, Mattson H, Larsson H. Proliferation of enterochromaffin-like (ECL) cells in the rat stomach following omeprazole treatment. Hepatogastroenterology 1985;32:48-9. 


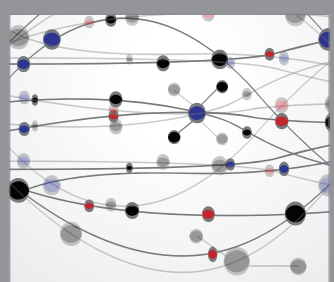

The Scientific World Journal
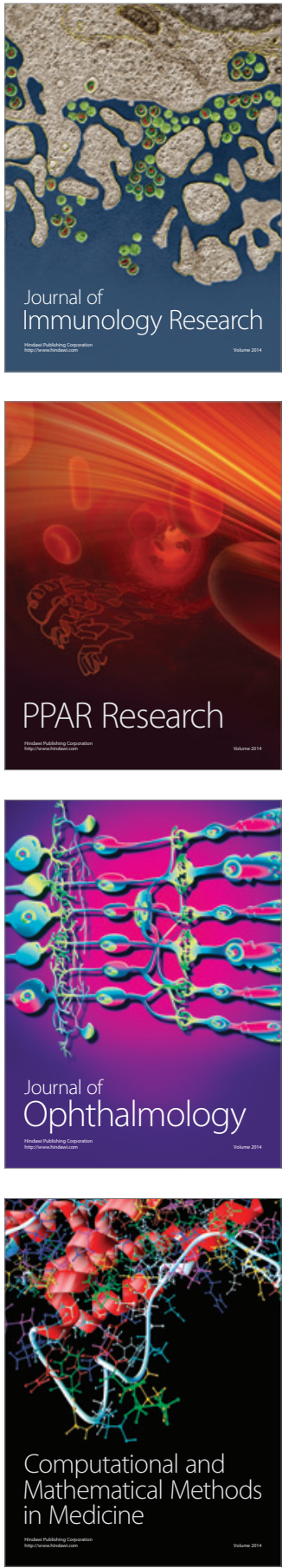

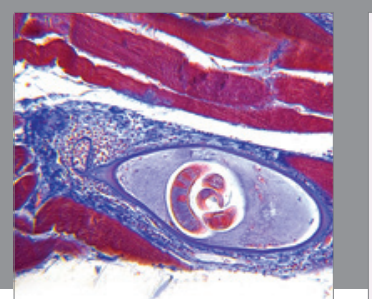

Gastroenterology Research and Practice

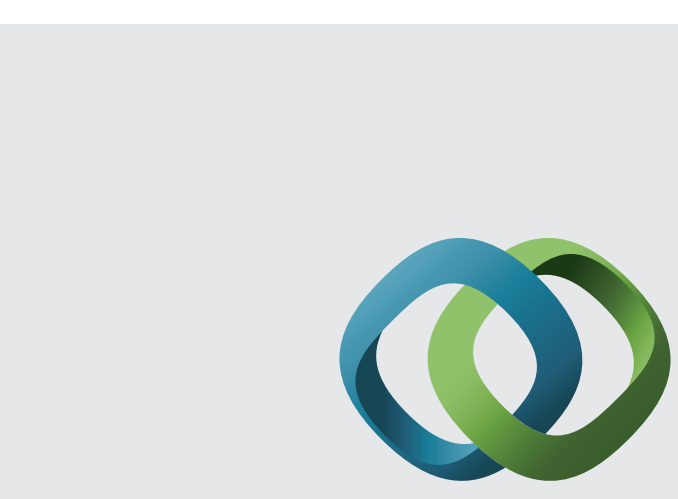

\section{Hindawi}

Submit your manuscripts at

http://www.hindawi.com
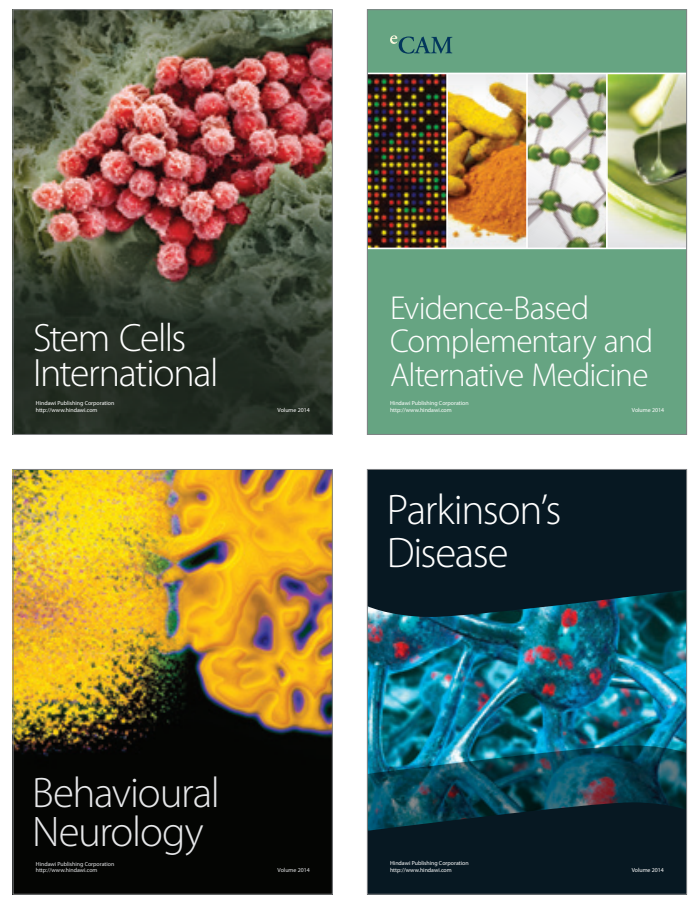
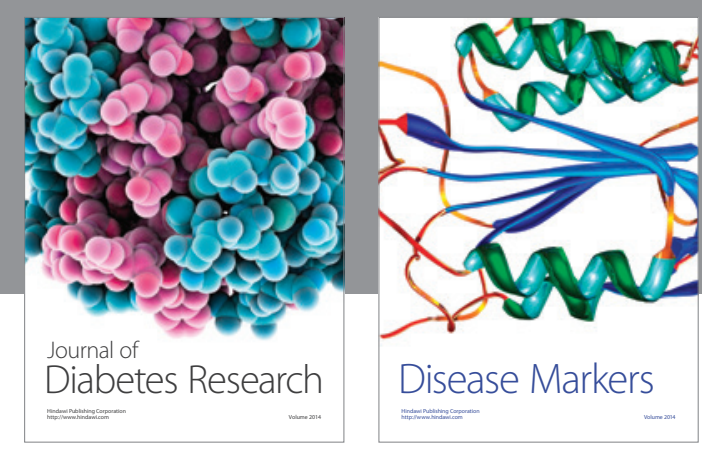

Disease Markers
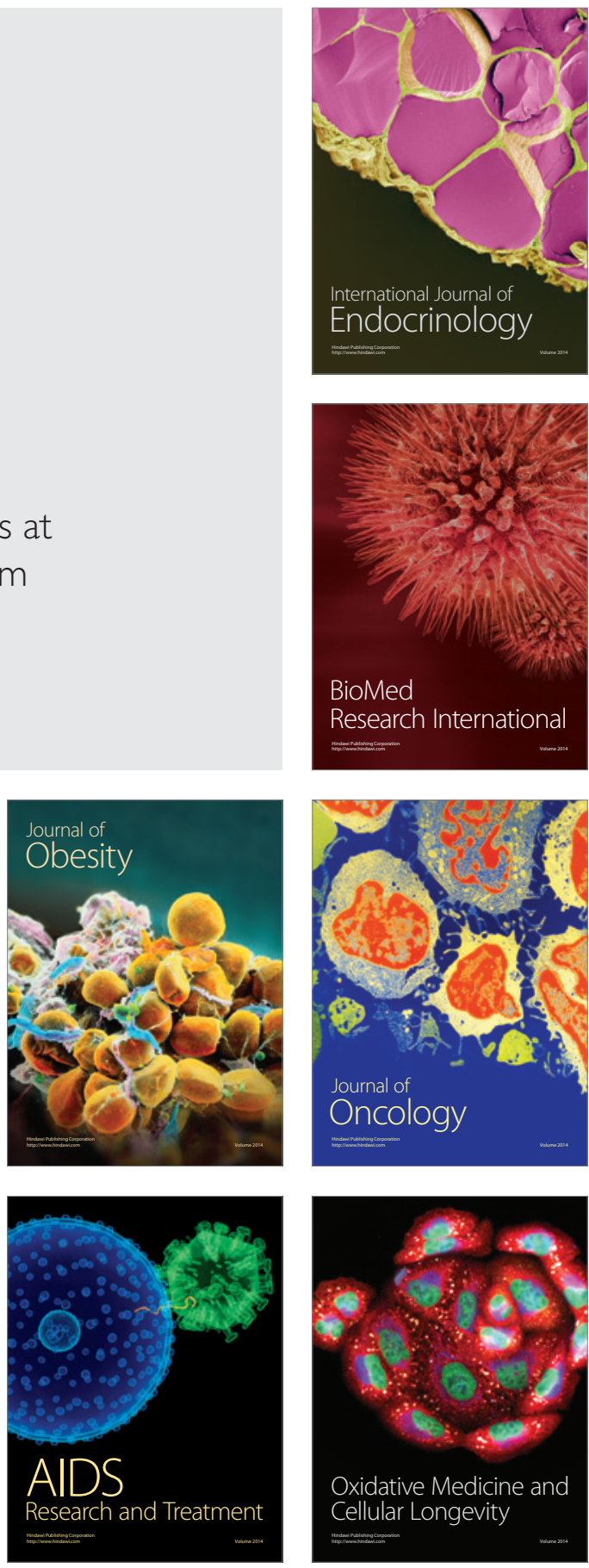